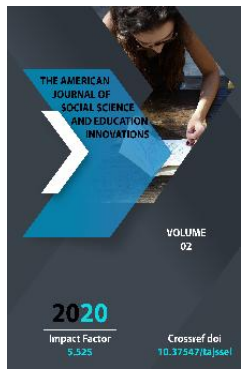

\title{
Some Issues Of Qualification Of The Involvement Of A Minor In Antisocial Behavior
}

\author{
Ashurova Nilufar Uktamovna \\ Independent Researcher At The Military Technical Institute Of The National Guard Of The \\ Republic Of Uzbekistan
}

Journal Website:

http://usajournalshub.c

om/index,php/tajssei

Copyright: Original

content from this work

may be used under the

terms of the creative

commons attributes

4.0 licence.

\section{ABSTRACT}

This article is aimed at strengthening the protection of the rights and freedoms of minors. The method of historical study is very helpful in revealing the content of criminal law norms, in fully understanding the essence of the existing criminal law prohibitions in them. By retrospectively observing a certain phenomenon, that is, when and how it appeared, what stages it went through in development, it is possible to explain its current state and determine its future development. The subject of the article is a theoretical analysis of scientific and practical problems of criminal liability for involving a minor in antisocial behavior, the norms of criminal law of the Republic of Uzbekistan and foreign countries for criminal involvement of a minor in antisocial behavior, scientific work on the problem under study. as well as case law on the specified category of crimes.

\section{KEYWORDS}

A minor, a crime, social danger, antisocial behavior, involvement of a minor in antisocial behavior, involving of minor into comment of offence.

\section{INTRODUCTION}

It is known that the prevention and fight against drug addiction today has become one of the most pressing global problems. This problem seriously worries not only our republic, but also the general public around the world. Therefore, the prevention of drug addiction and the organization of an effective fight against it require the unification of all forces and resources of the entire world community. The order in which this problem will be solved will determine the future of all mankind and give an idea of its scale. Its ignorance of territory, nation, religion, class, 
gender and other boundaries gives an idea of its scale.

Today, the illegal trade in narcotic drugs and psychotropic substances has become an unlimited force that poses a huge threat to humanity. As a result, a number of international conventions on prevention and control have been adopted. In particular, the 1961, 1971 and 1988 Conventions stipulated that in the fight against drugs, not only an international, but also an internal system of each state party should be created. The Republic of Uzbekistan is also a full party to international conventions on drug prevention and control and develops practical measures to comply with obligations under these conventions.

Thus, the Republic of Uzbekistan has adopted a number of legislative acts aimed at preventing and combating drug addiction. Prevention of drug addiction is unthinkable without the Constitution of the Republic of Uzbekistan. As stated in article 24 of the Constitution, "The right to life is an inalienable right of every person". Drug crimes are directed against the life and health of people, and drug addiction leads to the deprivation of such organic rights. Medicines and plants containing narcotic drugs are included in the list of medicines and are controlled in the Republic of Uzbekistan. These include, in addition to the definitions given in section 8 , articles included in Schedules I and II of the 1961 United Nations Convention on Narcotic Drugs under the 1972 Protocol amending the 1961 Joint Convention on Drugs.

The objective aspect of the crime under part 2 of Article 127 of the Criminal Code, is the involvement of an adult in the use of narcotic drugs or psychotropic substances by minors in various ways (deception, hospitality, deception, etc.).

Other plants containing narcotic or psychotropic substances may include the coca bush (from which cocaine is obtained) and other crops containing narcotic or psychotropic substances. These crops are characterized by a high content of narcotic drugs and psychotropic substances, therefore crops or parts of them are recognized as narcotic drugs in accordance with the decree of the State Commission for Drug Control. These crops can only be grown for the pharmaceutical industry or for scientific purposes [1].

Sane persons over 18 years of age who involve a minor in the use of narcotic drugs or psychotropic substances are found guilty.

Subjectively, the involvement of a minor in the use of narcotic drugs or psychotropic substances is deliberate.

In our opinion, in Article 274 of the Criminal Code it is advisable to qualify the act of involving a minor in the use of narcotic drugs, their analogues or psychotropic substances as an aggravating circumstance.

Chapter 19 of Article 6 of the Special Part of the Criminal Code of the Republic of Uzbekistan contains a list of crimes related to illegal handling of narcotic drugs or psychotropic substances. The cultivation of illegal crops, illegal storage of narcotic drugs or psychotropic substances, illegal transfer of narcotic drugs or psychotropic substances, illegal preparation, storage, storage and other actions for the purpose of trafficking in narcotic drugs or psychotropic substances, as well as their illegal use, illegal circulation, participation in the use of narcotic drugs or 
psychotropic substances, violation of the rules for the production or use of narcotic drugs or psychotropic substances, illegal preparation, storage, storage and other actions without the purpose of trafficking in narcotic drugs or psychotropic substances are crimes of illegal circulation.

E. V. Kachigina involves the involvement of a minor in the commission of a crime as a perpetrator or an accomplice in the commission of a crime [2].

The involvement of a minor in a crime is carried out through the active actions of the offender in relation to physical or mental impact on the minor, and it does not matter for which crime the offender committed a minor under the age of 18 years [3].

According to M.Kh. Rustambaev, involvement of a minor in a crime means the use of physical violence or psychological pressure on a minor, intimidation, extortion, deception, deception, revenge, jealousy, jealousy and other degrading feelings. It is clear that the excitement of intentions. Actions and offenses aimed at encouraging the intention to participate in the commission of one or more offenses by offering to commit a crime, promising to assist in the purchase or sale of stolen property, informing about the place and methods of committing a crime, or hiding the traces of a crime, it is important to understand alcohol consumption by minors in order to distract [4].

As you know, criminal law considers the committed crime as a legal fact. Criminal legal relations arise in connection with the commission of a crime. If the criminal act is not committed, criminal law relations do not arise, since the person is obliged to bear responsibility before the state in connection with the commission of the crime. A person commits socially dangerous acts prohibited by criminal law, and evokes such an attitude. Criminal liability arises from the obligation to be responsible [5].

The crime scene is defined as the specific law or premises where the crime was committed or a criminal consequence arose. In some cases, a crime scene is a necessary sign of a socially dangerous act. If the place of the crime is considered a necessary sign of the qualification of the crime, the qualification of the crime is decided in the same manner [6].

It is known that some features of Article 127 of the Criminal Code of the Republic of Uzbekistan can be reflected in crimes against the rights and interests of other minors. For example, it is worth focusing on aspects of them other than crimes against the sexual integrity of some minors.

Specifically, the difference between engaging a minor in antisocial behavior and having sex with a person under the age of sixteen is as follows:

a) if the object of the involvement of a minor in antisocial behavior is the moral, health and public order of the minor, that is, public safety, then the object of the crime of sexual intercourse with a person under the age of sixteen is the sexual crime of a minor invulnerability [7].

b) if the involvement of a minor in antisocial behavior has an administrative bias, the law does not provide for an administrative bias in relation to sexual intercourse with a person under the age of sixteen. 
c) The involvement of a minor in antisocial behavior is usually determined by law. A necessary indication of sexual intercourse with a person under the age of sixteen is that the crime was committed on a voluntary basis;

d) if the subject is a sane person who has reached the age of 18 , in order to involve a minor in antisocial behavior, the responsibility for sexual relations with a person under the age of sixteen is set at 16 years.

According to legal sources, teenagers are more often involved in crime and alcoholism by persons aged 18-20 years. For example, a study conducted by

V.K. Negodenko, showed that $18-20$ years old make up 48.2 percent of all recruiters and demonstrators. The majority of adults involved in crime and alcoholism are 16-17 years old, accounting for 70.7 percent of all those involved in this [8].

The differences between the involvement of a minor in antisocial behavior and the crime of indecent acts against a person under the age of sixteen are as follows:

These crimes are socially close to each other. Both the involvement of minors in antisocial behavior and sexual intercourse with persons under the age of sixteen harm the normal development of minors, both morally and physically, and their development in adulthood. In addition to involving minors in various types of antisocial behavior, the perpetrators of both crimes also use them to commit various criminal acts in their own interests.

In our opinion, the normal family, spiritual and moral development of a minor, his health should be considered as a direct object of involving a minor in antisocial behavior.

\section{CONCLUSION}

Various types of antisocial behavior are common among minors today, including begging, begging and not being able to live in one place. However, the involvement of a minor in begging, alcohol consumption or the use of drugs or substances that are not considered narcotic or psychotropic, but affect a person's consciousness, although in the future this may lead to criminal consequences, in this case it is considered a socially dangerous act. Excluded. The legislator himself assumes that this should be the main administrative responsibility.

\section{REFERENCES}

1. Article 21 of the Law of the Republic of Uzbekistan "On Narcotic Drugs and Psychotropic Substances" dated August 19, 1999.

2. Criminal law of the Russian Federation. 2005. - p. 287.

3. Rustamboev M.Kh. Basic law course of the Republic of Uzbekistan. A special time. 3-Volume; Crimes against the person. Crimes against peace and security. Textbook for Universities. Tashkent .: Publishing house of TSIL, 2009. - P. 225.

4. Criminal law. Special section. Tashkent, TSIL. 2003. P. 117.

5. Usmonaliev M. Problems of modern criminal law (textbook). -Tashkent. TSIL., 2007. - P. 49.

6. M.Kh. Rustamboev. Commentary on the Criminal Code. -Tashkent., 2005. - P. 81.

7. M.Kh. Rustamboev. Commentary on the Criminal Code. -Tashkent., 2005. -P. 81. 
The American Journal of Social Science and Education Innovations (ISSN - 2689-100x)

Published: November 28, 2020 | Pages: 248-252

Doi: https://doi.org/10.37547/tajssei/Volumeo2Issue11-44

2020:5. 525

8. Theoretical problems of preventing juvenile delinquency. Kiev. 1987., 143 p. 